\title{
Early diabetes-induced biochemical changes in the retina: comparison of rat and mouse models
}

\author{
I. G. Obrosova • V. R. Drel • A. K. Kumagai • C. Szábo • \\ P. Pacher • M. J. Stevens
}

Received: 3 January 2006 / Accepted: 22 May 2006 / Published online: 1 August 2006

(C) Springer-Verlag 2006

\begin{abstract}
Aims/hypothesis Recently, various transgenic and knockout mouse models have become available for studying the pathogenesis of diabetic retinopathy. At the same time, diabetes-induced retinal changes in the wild-type mice remain poorly characterised. The present study compared retinal biochemical changes in rats and mice with similar (6-week) durations of streptozotocin-induced diabetes.

Materials and methods The experiments were performed on Wistar rats and C57B16/J mice. Retinal glucose, sorbitol, fructose, lactate, pyruvate, glutamate, $\alpha$-ketoglutarate and ammonia were measured spectrofluorometrically by enzymatic methods. Vascular endothelial growth factor (VEGF) protein
\end{abstract}

\footnotetext{
I. G. Obrosova $(\bowtie) \cdot$ V. R. Drel

Pennington Biomedical Research Center,

Louisiana State University System,

6400 Perkins Road,

Baton Rouge, LA 70808, USA

e-mail: obrosoig@pbrc.edu
}

I. G. Obrosova • A. K. Kumagai • M. J. Stevens

Department of Internal Medicine, University of Michigan,

Ann Arbor, MI, USA

C. Szábo

Inotek Pharmaceuticals Corporation,

Beverly, MA, USA

Present address:

C. Szábo

Department of Human Physiology and Experimental Research,

Semmelweis University,

Budapest, Hungary

P. Pacher

Laboratory of Physiological Studies,

NIH/NIAAA,

Bethesda, MD, USA was assessed by ELISA, and poly(ADP-ribosyl)ation by immunohistochemistry and western blot analysis. Free mitochondrial and cytosolic $\mathrm{NAD}^{+} / \mathrm{NADH}$ ratios were calculated from the glutamate and lactate dehydrogenase systems.

Results Retinal glucose concentrations were similarly increased in diabetic rats and mice, vs controls. Diabetic rats manifested $\sim 26$ - and 5-fold accumulation of retinal sorbitol and fructose, respectively, whereas elevation of both metabolites in diabetic mice was quite modest. Correspondingly, diabetic rats had (1) increased retinal malondialdehyde plus 4-hydroxyalkenal concentrations, (2) reduced superoxide dismutase (SOD), glutathione peroxidase, glutathione reductase and glutathione transferase activities, (3) slightly increased poly(ADP-ribose) immunoreactivity and poly(ADP-ribosyl)ated protein abundance, and (4) VEGF protein overexpression. Diabetic mice lacked these changes. SOD activity was 21 -fold higher in murine than in rat retinas (the difference increased to 54-fold under diabetic conditions), whereas other antioxidative enzyme activities were 3- to 10-fold lower. With the exception of catalase, the key antioxidant defence enzyme activities were increased, rather than reduced, in diabetic mice. Diabetic rats had decreased free mitochondrial and cytosolic $\mathrm{NAD}^{+} /$ NADH ratios, consistent with retinal hypoxia, whereas both ratios remained in the normal range in diabetic mice.

Conclusions/interpretation Mice with short-term streptozotocin-induced diabetes lack many biochemical changes that are clearly manifest in the retina of streptozotocin-diabetic rats. This should be considered when selecting animal models for studying early retinal pathology associated with diabetes.

Keywords Mouse $\cdot \mathrm{NAD}^{+} / \mathrm{NADH}$ ratio $\cdot$ Oxidative stress . Poly(ADP-ribosyl)ation $\cdot$ Rat $\cdot$ Retina $\cdot$ Sorbitol pathway of glucose metabolism $\cdot$ Streptozotocin diabetes $\cdot$ Vascular endothelial growth factor 


$\begin{array}{ll}\text { Abbreviations } \\ \text { AR } & \text { aldose reductase } \\ \text { GFAP } & \text { glial fibrillary acidic protein } \\ \text { GSH } & \text { reduced glutathione } \\ \text { GSHPx } & \text { glutathione peroxidase } \\ \text { GSSGRed } & \text { glutathione reductase } \\ \text { GSHTrans } & \text { glutathione transferase } \\ \text { 4-HA } & \text { 4-hydroxyalkenals } \\ \text { MDA } & \text { malondialdehyde } \\ \text { PARP } & \text { poly(ADP-ribose) polymerase } \\ \text { SOD } & \text { superoxide dismutase } \\ \text { STZ } & \text { streptozotocin } \\ \text { VEGF } & \text { vascular endothelial growth factor }\end{array}$

\section{Introduction}

Diabetic retinopathy results from a complex interplay between multiple pathogenetic processes, developing in both retinal vasculature and the neural retina [1]. The most important pathogenetic mechanisms, such as increased aldose reductase (AR) activity, non-enzymatic glycation, activation of protein kinase C, oxidative-nitrosative stress, and, recently, poly (ADP-ribose) polymerase (PARP) activation, have been identified in experimental studies in diabetes and diabeteslike models of early and advanced retinopathy in rats [2-11] and dogs $[12,13]$. The recent availability of transgenic mice provides a powerful tool for dissecting new pathogenetic mechanisms and exploring interactions among those already established. Furthermore, tissue-specific overexpression or knock-down of specific genes creates the possibility of exploring the role of vascular and non-vascular mechanisms in the pathogenesis of diabetic retinopathy.

Whereas the presence of such phenomena as sorbitol pathway hyperactivity $[3,4,14], \mathrm{NAD}^{+} / \mathrm{NADH}$ redox imbalances [15, 16], oxidative-nitrosative stress [6, 17-19], vascular endothelial growth factor (VEGF) overexpression [9, $14,20,21]$, and, recently, PARP activation [11, 19, 21], is well documented in the diabetic rat retina, the corresponding information in diabetic mice is scarce and often based on single-source data [22]. The primary goal of this study was to compare early biochemical changes in diabetic rats and mice with similar (6-week) durations of streptozotocin (STZ)induced diabetes. Note, that a biochemical approach identifies changes in the whole retina composed primarily of nonvascular cells (vasculature: $1-1.5 \%$, non-vascular elements: 98.5-99\%). Thus, the secondary goal of our experiments was to evaluate the suitability of the STZ-mouse model for studying the contribution of specific biochemical mechanisms (increased sorbitol pathway activity, oxidative stress, PARP activation, VEGF overexpression, $\mathrm{NAD}^{+} / \mathrm{NADH}$ redox imbalances) to early retinal pathology associated with diabetes.

\section{Materials and methods}

Animals and animal care

The experiments were performed in accordance with regulations specified by The Guiding Principles in the Care and Use of Animals (DHEW Publication, NIH 80-23) and Pennington Biomedical Research Center and University of Michigan Protocols for Animal Studies.

Barrier-sustained, Caesarean-delivered male Wistar rats, initial body weights $220-255 \mathrm{~g}$, and male C57B16/J mice, initial body weights $25 \mathrm{~g}$ (both obtained from Charles River, Wilmington, MA, USA), were fed a standard rat and mouse chow and had free access to water. Diabetes was induced by a single i.p. injection of STZ $(50 \mathrm{mg} / \mathrm{kg}$ body weight to rats and $150 \mathrm{mg} / \mathrm{kg}$ to mice). Blood samples for measurements of glucose were taken from the tail vein $\sim 48 \mathrm{~h}$ after STZ injection and the day before the animals were killed. Rats and mice with blood glucose $\geq 14 \mathrm{mmol} / 1$ were considered diabetic. The duration of the experiment was 6 weeks.

\section{Reagents}

Unless otherwise stated, all chemicals were of reagent-grade quality, and were purchased from Sigma Chemical, St Louis, MO, USA. Methanol (HPLC grade), perchloric acid, hydrochloric acid and sodium hydroxide were obtained from Fisher Scientific, Pittsburgh, PA, USA. Ethyl alcohol (200 proof dehydrated alcohol, USP punctilious) was purchased from McCormick Distilling, Weston, MO, USA. $\beta$-D-Glucose, sorbitol NF, and D-fructose USP were purchased from Pfanstiehl Laboratories, Waukegan, IL, USA. Kits for measurements of malondialdehyde (MDA) and 4-hydroxyalkenals (4-HA) and glutathione peroxidase activity were purchased from Oxis International, Portland, OR, USA, kits for VEGF protein measurements and VEGF protein standards from R\&D Systems, Minneapolis, MN, USA, and bicinchoninic acid (BCA) protein assay kits from Pierce, Rockford, IL, USA. Reagents for immunohistochemistry were purchased from Vector Laboratories, Burlingame, CA, USA. Monoclonal anti-PARP antibody, clone C-2-10, and monoclonal anti-poly(ADP-ribose) antibody were obtained from Biomol, Plymouth Meeting, PA, USA.

Experimental procedures

Animals were sedated with carbon dioxide in a specially designed chamber [23] and immediately killed by cervical dislocation. Both retinas were rapidly dissected and frozen in liquid nitrogen. Three retinas from three rats and eight retinas from eight mice were pooled for each VEGF protein 
measurement by ELISA. MDA plus 4-HA were assessed in individual rat retinas, whereas four mouse retinas were pooled together for each such measurement. Other metabolic parameters, i.e. glucose, sorbitol, fructose, lactate, pyruvate, glutamate, $\alpha$-ketoglutarate, ammonia and reduced glutathione (GSH), as well as superoxide dismutase (SOD), catalase, glutathione peroxidase (GSHPx), glutathione reductase (GSSGRed) and glutathione transferase (GSHTrans) activities were assessed in individual rat and mouse retinas.

Individual measurements

\section{Sorbitol pathway intermediates}

These were measured in individual retinas spectrofluorometrically by enzymatic procedures [24].

\section{ELISA for VEGF}

Material from three rat retinas or eight mouse retinas was homogenised in $0.2 \mathrm{ml} 50 \mathrm{mmol} / 1$ Tris buffer $(\mathrm{pH} \mathrm{8.0)}$ and centrifuged at $10,000 \mathrm{~g}$ for $10 \mathrm{~min}$ (Sorvall MC 12V). Aliquots $(50 \mu \mathrm{l})$ of the supernatant were used for VEGF measurements. VEGF was assayed by a sandwich ELISA with an affinity-purified polyclonal antibody specific for mouse VEGF and mouse VEGF standard. VEGF concentrations were normalised to total protein.

\section{MDA plus 4-HA}

For measurement of MDA plus 4-HA, we used $200 \mu \mathrm{l}$ of the retinal homogenates obtained as above. The method is based on the reaction of a chromogenic reagent, $N$-methyl2-phenylindole, with MDA and $4-\mathrm{HA}$ at $45^{\circ} \mathrm{C}$, and is specific for free MDA and 4-HA.

\section{Antioxidative defence enzyme activities}

The remaining retinal homogenate from above was centrifuged at $4,000 \mathrm{~g}$ for $10 \mathrm{~min}$. The supernatants were used for spectrophotometric measurements of SOD, catalase, GSSGRed, GSHPx and GSHTrans activities $[14,17]$.

\section{Metabolites of glycolysis and the tricarboxylic acid cycle and $G S H$}

Following deproteinisation with perchloric acid (1 $\mathrm{ml} 6 \%$ $\mathrm{HClO}_{4}$ per retina), the levels of lactate, pyruvate, glutamate, $\alpha$-ketoglutarate and ammonia, as well as GSH, were assayed in neutralised extracts spectrofluorometrically as described previously [16, 17].

\section{Protein}

All concentrations are expressed in nanomoles per milligram protein. Protein levels were quantified with Pierce BCA protein assay kits.

\section{Poly(ADP-ribose) immunohistochemistry}

All immunohistochemical samples were coded and examined by a single investigator in a blinded fashion. Paraffin-embedded 5- $\mu$ m-thick longitudinal sections of the whole eye were deparaffinised in xylene and rehydrated in decreasing concentrations of ethanol followed by a 5-min incubation in PBS. To detect poly(ADPribose), a routine histochemical procedure was applied as previously described [19].

\section{Western blot analyses of PARP-1 and poly(ADP-ribose)}

To assess PARP-1 and poly(ADP-ribosyl)ated proteins by western blot analysis, two pooled retinas from each rat or mouse were placed in $200 \mu \mathrm{l}$ of an extraction buffer containing $50 \mathrm{mmol} / 1$ Tris- $\mathrm{HCl}$, pH 7.2; $150 \mathrm{mmol} / \mathrm{l} \mathrm{NaCl}$; 0.1\% SDS; 1\% NP-40; 5 mmol/1 EDTA; 1 mmol/1 EGTA; $1 \%$ sodium deoxycholate; and the protease/phosphatase inhibitors leupeptin $(10 \mu \mathrm{g} / \mathrm{ml})$, aprotinin $(20 \mu \mathrm{g} / \mathrm{ml})$, benzamidine (10 mmol/l), phenylmethylsulphonyl fluoride (1 $\mathrm{mmol} / \mathrm{l}$ ) and sodium orthovanadate $(1 \mathrm{mmol} / \mathrm{l})$. The retinas were then homogenised on ice. The homogenate was sonicated $(3 \times 5 \mathrm{~s})$ and centrifuged at $14,000 \mathrm{~g}$ for $20 \mathrm{~min}$. All the aforementioned steps were performed at $4^{\circ} \mathrm{C}$. The lysates $(20 \mu \mathrm{g}$ protein) were mixed with equal volumes of $2 \times$ sample-loading buffer containing $62.5 \mathrm{mmol} / 1$ Tris$\mathrm{HCl}, \mathrm{pH} 6.8 ; 2 \%$ SDS; 5\% $\beta$-mercaptoethanol; $10 \%$ glycerol and $0.025 \%$ bromophenol blue; they were then fractionated in 10\% SDS-PAGE in an electrophoresis cell (Mini-Protean III; Bio-Rad Laboratories, Richmond, CA, USA). Electrophoresis was conducted at $15 \mathrm{~mA}$ constant current for stacking, and at $25 \mathrm{~mA}$ for protein separation. Gel contents were electrotransferred $(250 \mathrm{~mA}, 2 \mathrm{~h})$ to nitrocellulose membranes using a Mini Trans-Blot cell (Bio-Rad) and western transfer buffer $(25 \mathrm{mmol} / \mathrm{l}$ Tris- $\mathrm{HCl}$, pH 8.3; $192 \mathrm{mmol} / 1$ glycine; and 20\% (v/v) methanol) [25]. Free binding sites were blocked in $2 \%(\mathrm{w} / \mathrm{v}) \mathrm{BSA}$ in

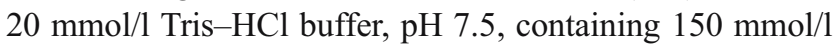
$\mathrm{NaCl}$ and $0.05 \%$ Tween 20 , for $1 \mathrm{~h}$, after which poly(ADPribose) antibody was applied for $2 \mathrm{~h}$ for detection of poly (ADP-ribosyl)ated proteins. The horseradish-peroxidaseconjugated secondary antibody was then applied for $1 \mathrm{~h}$. After extensive washing, protein bands detected by the antibodies were visualised with the BM Chemiluminescence Blotting Substrate (POD; Roche, Indianapolis, IN, USA). Membranes were then stripped in the $62.5 \mathrm{mmol} / 1$ 
Tris-HCl, pH 6.7 buffer containing 2\% SDS and $100 \mathrm{mmol} / \mathrm{l} \beta$-mercaptoethanol, and reprobed with PARP-1 antibody as well as with $\beta$-actin antibody to confirm equal protein loading. The content of PARP-1 and poly (ADP-ribosyl)ated proteins was quantified by densitometry (Quantity One 4.5.0 software; Bio-Rad).

Statistical analysis

The results are expressed as means \pm SEM. Individual comparisons between control and diabetic rats or mice were made using the unpaired two-tailed Student's $t$-test or Mann-Whitney rank-sum test where appropriate. Significance was defined at $p \leq 0.05$.

\section{Results}

Body weights were lower in diabetic rats and mice with a 6-week duration of STZ diabetes than in the corresponding control groups (Table 1). Blood glucose concentrations were similarly increased in diabetic rats and mice compared with non-diabetic controls.

Retinal glucose, sorbitol and fructose concentrations were 5.8-, 26- and 4.7-fold higher in diabetic rats than in controls (Table 2). Retinal glucose accumulation in diabetic mice amounted to 5.3-fold, and was comparable with that in diabetic rats. However, the diabetes-associated increase in retinal sorbitol (1.7-fold) and fructose (1.8-fold) concentrations in the mouse model was quite modest compared with the rat model.

Retinal MDA plus 4-HA concentration was increased 1.5 -fold in diabetic rats compared with controls (Table 3 ) whereas diabetic mice retained normal lipid peroxidation product levels. GSH concentrations remained in the normal range in both animal groups. SOD, GSHPx, GSHTrans and GSSGRed activities were decreased 1.9-, 1.8-, 2.2- and 1.8fold, respectively, in diabetic rats compared with controls, whereas catalase activity was slightly (1.3-fold) but significantly $(p<0.01)$ increased. A different pattern of

Table 1 Final body weights and blood glucose concentrations in experimental rats and mice

\begin{tabular}{lll}
\hline Group & Body weight $(\mathrm{g})$ & Blood glucose $(\mathrm{mmol} / \mathrm{l})$ \\
\hline Rat & & \\
Control & $467 \pm 8$ & $4.23 \pm 0.13$ \\
Diabetic & $397 \pm 22^{* *}$ & $20.1 \pm 1.47^{* *}$ \\
Mouse & & \\
Control & $31.1 \pm 0.3$ & $5.33 \pm 0.23$ \\
Diabetic & $23.8 \pm 0.6^{* *}$ & $22.4 \pm 0.80^{* *}$ \\
\hline
\end{tabular}

Values are means \pm SEM, $n=20-32$

$* * p<0.01$ for difference from controls
Table 2 Retinal sorbitol pathway intermediate concentrations (nmol/mg protein) in experimental rats and mice

\begin{tabular}{llll}
\hline Group & Glucose & Sorbitol & Fructose \\
\hline Rat & & & \\
Control & $15.6 \pm 2.3$ & $1.02 \pm 0.18$ & $8.92 \pm 0.2$ \\
Diabetic & $90.4 \pm 6.6^{* *}$ & $26.6 \pm 4.6^{* *}$ & $42.2 \pm 2.9^{* *}$ \\
Mouse & & & \\
Control & $9.7 \pm 0.9$ & $1.19 \pm 0.20$ & $7.36 \pm 0.35$ \\
Diabetic & $51.8 \pm 2.9^{* *}$ & $1.99 \pm 0.30^{*}$ & $13.6 \pm 1.12^{* *}$ \\
\hline
\end{tabular}

Values are mean \pm SEM, $n=6-8$

$* p<0.05, * * p<0.01$ for difference from controls

antioxidant enzyme defence was observed in the mouse model. In particular, SOD activity was 21 -fold higher in murine than in rat retina, whereas other antioxidative enzyme activities were instead 3- to 10-fold lower. In diabetic conditions, the key antioxidative defence enzyme activities were increased rather than reduced. In particular, GSHPx, GSHTrans and GSSGRed activities were increased 1.4-, 2- and 1.6-fold, respectively. SOD activity was increased 1.4-fold, which increased the difference with the corresponding variable in the diabetic rat to 54-fold in favour of the mouse. In contrast to the findings in the diabetic rat model, catalase activity was reduced (1.7-fold), rather than increased.

PARP-1 protein abundance was similar in control and diabetic rats as well as in control and diabetic mice (not shown). Poly(ADP-ribosyl)ated protein abundance (an index of PARP-1 activity) tended to increase in diabetic

Table 3 Retinal lipid peroxidation product (MDA+4-HA) and GSH concentrations (nmol/mg protein), and antioxidative defence enzyme activities (nmol substrate $\mathrm{mg}$ protein ${ }^{-1} \cdot \mathrm{min}^{-1}$ ) in experimental mice and rats

\begin{tabular}{lll}
\hline Variable & Control & Diabetic \\
\hline Rat & & \\
MDA+4-HA & $2.5 \pm 0.16$ & $3.7 \pm 0.3^{* *}$ \\
GSH & $15 \pm 2$ & $15 \pm 1$ \\
SOD & $3.5 \pm 0.5$ & $1.9 \pm 0.27^{*}$ \\
Catalase & $69 \pm 4$ & $88 \pm 3^{* *}$ \\
GSSGRed & $10 \pm 1$ & $5.3 \pm 0.6^{* *}$ \\
GSHPx & $39 \pm 6$ & $2 \pm 4^{*}$ \\
GSHTrans & $182 \pm 31$ & $84 \pm 13^{*}$ \\
Mouse & & \\
MDA+4-HA & $0.811 \pm 0.2$ & $0.815 \pm 0.34$ \\
GSH & $18 \pm 2$ & $21 \pm 2$ \\
SOD & $74 \pm 7$ & $102 \pm 10^{*}$ \\
Catalase & $3.4 \pm 0.7$ & $2.0 \pm 0.28^{*}$ \\
GSSGRed & $5.5 \pm 0.7$ & $9.2 \pm 0.8^{* *}$ \\
GSHPx & $4.2 \pm 0.3$ & $5.9 \pm 0.5^{*}$ \\
GSHTrans & $12 \pm 2$ & $24 \pm 3^{* *}$ \\
\hline
\end{tabular}

Values are means \pm SEM, $n=5-10$

${ }^{*} p<0.05,{ }^{* *} p<0.01$ for difference from controls 
rats, although the difference from non-diabetic controls did not achieve statistical significance (Fig. 1a,c). Poly(ADPribosyl)ated protein abundance was similar in control and diabetic mice (Fig. 1b,d). The results of western blot analysis are consistent with the immunohistochemistry findings. Scarce poly(ADP-ribose) immunoreactivity (a sign of PARP activation) was present in the inner neuronal and ganglion cell layers of diabetic rats (Fig. 2a) but not diabetic mice (Fig. 2b).

Retinal VEGF protein concentration was increased 1.8fold in diabetic rats compared with the control group $(33 \pm 3$ vs $18 \pm 2 \mathrm{pg} / \mathrm{mg}, p<0.01$, mean \pm SEM, $n=6-7)$. Retinal VEGF protein concentrations in the diabetic mice were similar to those in non-diabetic controls ( $40 \pm 2 \mathrm{vs} 42 \pm 3 \mathrm{pg} / \mathrm{mg}$, mean \pm SEM, $n=7-9$ ).

Retinal glutamate and $\alpha$-ketoglutarate concentrations were reduced 1.6- and 1.9-fold in diabetic rats (Table 4), whereas diabetic mice maintained normal concentrations of both metabolites. Retinal ammonia concentrations were reduced 1.5-fold in diabetic rats, and 1.2-fold in diabetic mice. Retinal pyruvate and lactate concentrations were reduced 1.8- and 1.4-fold in diabetic rats, whereas both metabolite concentrations were preserved in the normal range in diabetic mice.

Retinal free mitochondrial and cytosolic $\mathrm{NAD}^{+} / \mathrm{NADH}$ ratios were reduced 2 - and 1.5 -fold in diabetic rats, whereas diabetic mice maintained a normal redox state of both free mitochondrial and cytosolic NAD-couples.

\section{Discussion}

In our study, rats and mice with similar (6-week) duration of STZ diabetes had comparable levels of hyperglycaemia and retinal glucose accumulation. Therefore, the observed differences in diabetes-associated retinal metabolic abnormalities in the two animal models cannot be attributed to the distinctions in systemic or retinal glucose concentrations.
Fig. 1 a, b Representative western blot analyses of retinal poly(ADP-ribosyl)ated proteins in rats and mice, respectively. Equal protein loading was confirmed with $\beta$-actin antibody. $C$ Control groups, $D$ diabetic groups. c, d Total poly(ADPribosyl)ated protein content in retinas of rats (c) and mice (d). Data are means \pm SEM, $n=5$. Total poly(ADP-ribosyl)ated protein content in control rats is taken as $100 \%$ a

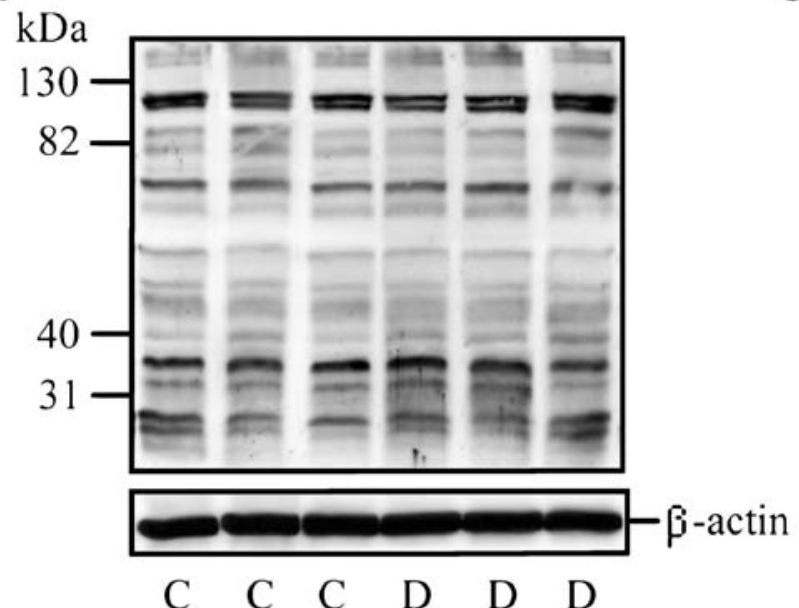

b

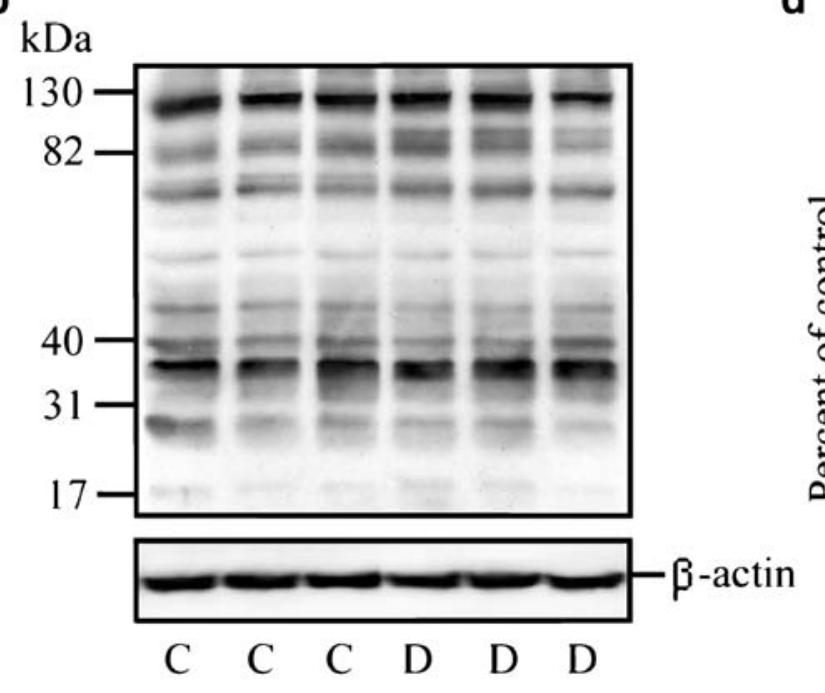

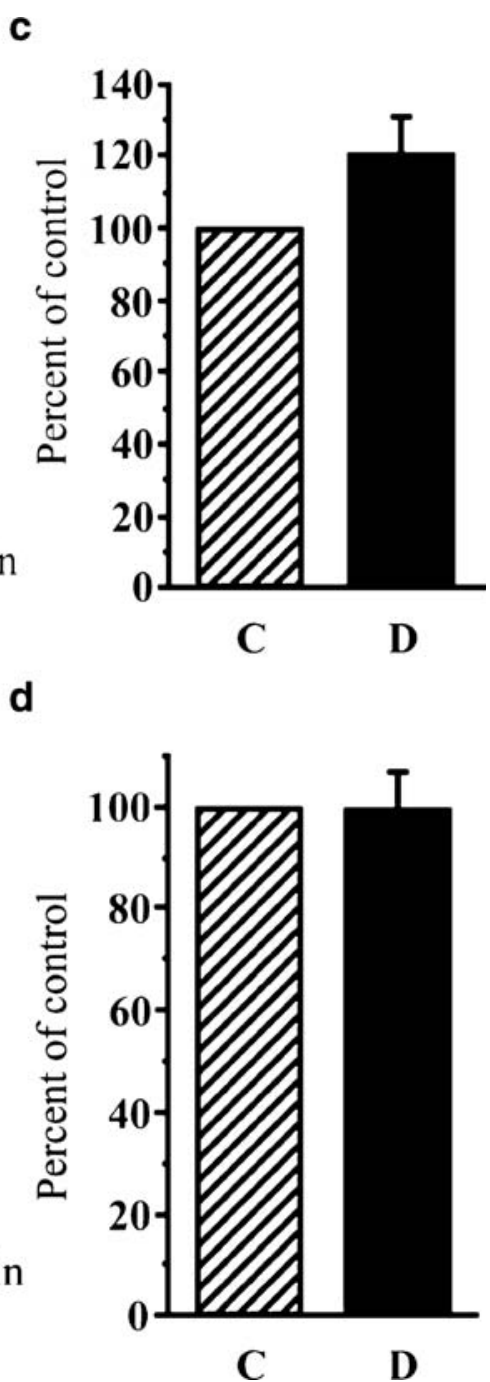


Fig. 2 Representative microphotographs of poly(ADP-ribose) immunostaining (arrows) in control and diabetic rats (a) and mice (b) ( $n=6$ per group). Magnification $\times 400$ a

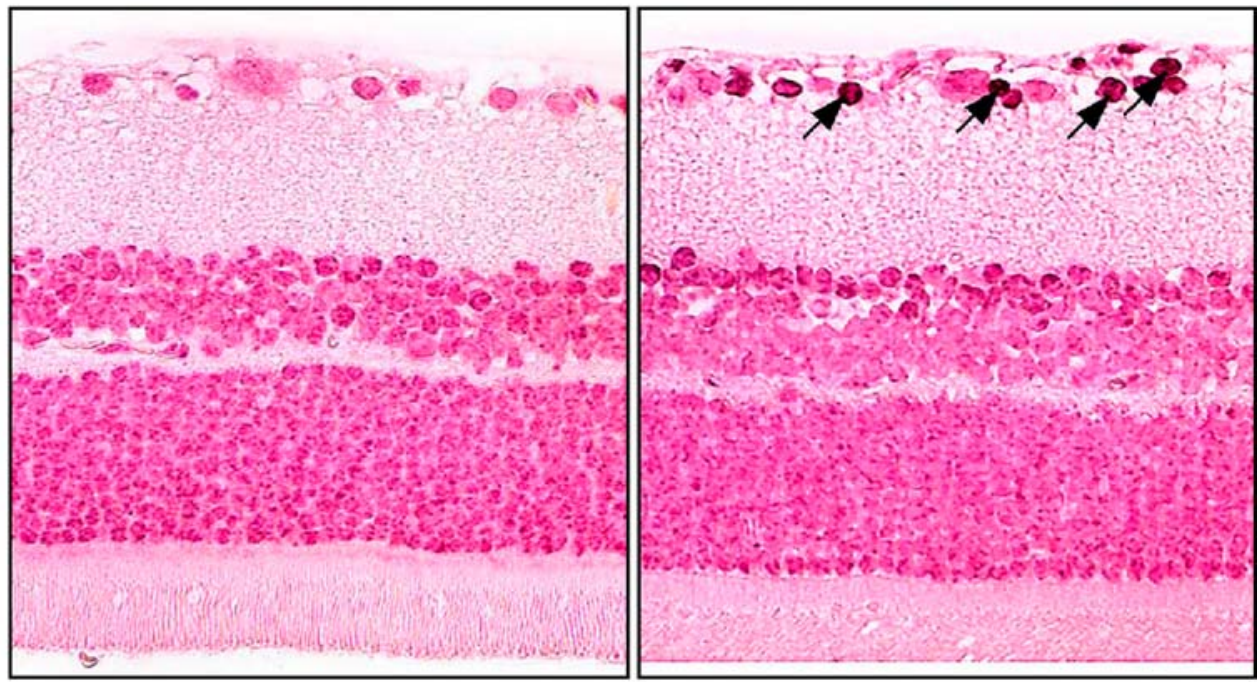

b

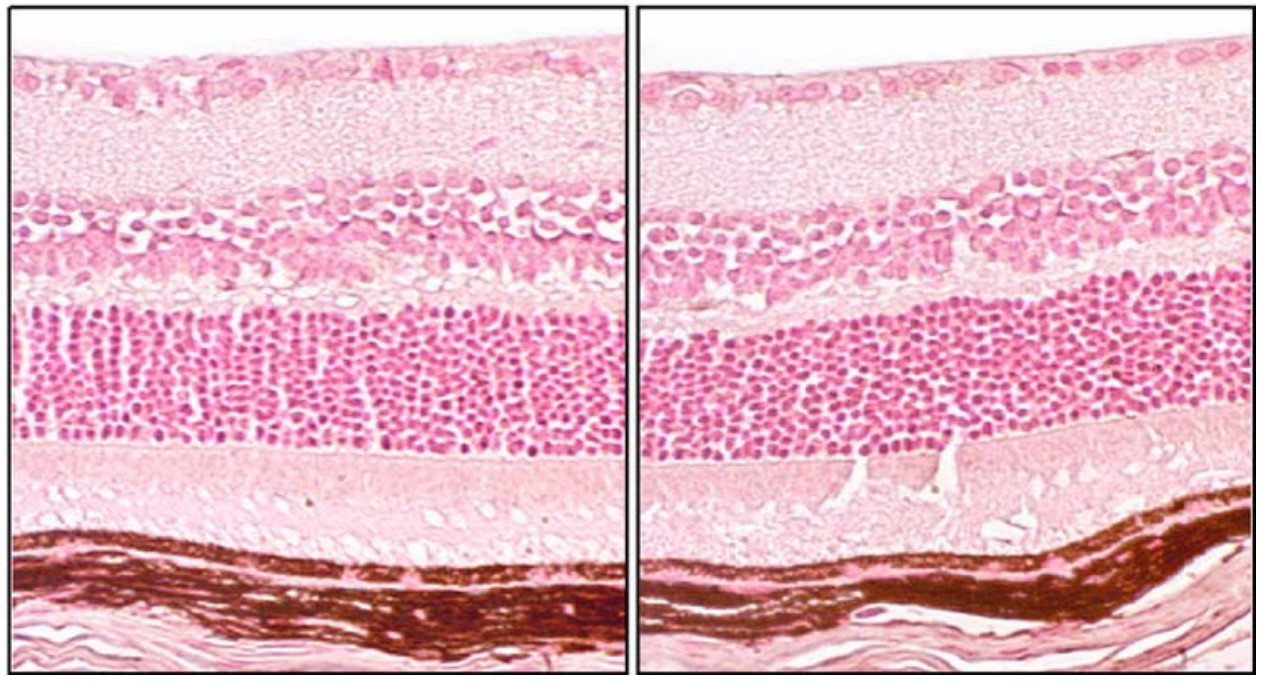

A dramatic activation of the sorbitol pathway of glucose metabolism, manifest by $26-$ and 4.7 -fold accumulation of retinal sorbitol and fructose, was present in the diabetic rats. This is in agreement with our previous studies and findings of other groups [3, 4, $14,16,19]$. In contrast, diabetes in mice caused a modest elevation of the retinal sorbitol pathway activity. Numerous findings indicate that increased activity of the first enzyme of the sorbitol pathway, AR, contributes to increased vascular permeability [26, 27] and leucocyte adhesion to the endothelial wall [28, 29], accelerated pericyte and endothelial cell apoptosis [4, 30] and formation of pericyte ghosts and acellular capillaries [2, 4], as well as VEGF overexpression [3, 14, 31] and neovascularisation [12, 27] associated with diabetic and diabetes-like retinopathy. Furthermore, increased AR activity is also involved in the accelerated apoptosis of inner retinal neurons and increased expression of glial fibrillary acidic protein (GFAP) in Muller glial cells [32]. All these phenomena, except neovascularisation, have been described in diabetic rats, and have been found preventable by treatment with AR inhibitors [4, 14, 26, 28]. In contrast, diabetic mice with modest sorbitol pathway hyperactivity were protected from neuronal apoptosis and changes in GFAP [32]. However, STZdiabetic mice do develop background diabetic retinopathy [33], which suggests that either the diabetes-induced increase in AR activity is much more abundantly expressed in vascular than neural mouse retina or increased AR activity is not necessarily required for development of this complication.

Diabetic rats have enhanced retinal oxidative stress manifest by accumulation of lipid peroxidation products and reduced activities of the key antioxidative defence enzymes including SOD, GSHPx, GSSGRed and GSHTrans. Oxidative stress is one of the key factors 
Table 4 Steady-state metabolite concentrations of the lactate dehydrogenase and glutamate dehydrogenase systems (nmol/mg protein) and free mitochondrial and cytosolic $\mathrm{NAD}^{+} / \mathrm{NADH}$ ratios in experimental mice and rats

\begin{tabular}{|c|c|c|}
\hline Variable & Control & Diabetic \\
\hline \multicolumn{3}{|l|}{ Rat } \\
\hline Pyruvate & $4.0 \pm 0.4$ & $2.2 \pm 0.24 * *$ \\
\hline Lactate & $79 \pm 3$ & $55 \pm 5^{* *}$ \\
\hline Glutamate & $49 \pm 3$ & $30 \pm 2 * *$ \\
\hline$\alpha$-Ketoglutarate & $7.2 \pm 0.3$ & $3.8 \pm 0.3 * *$ \\
\hline Ammonia & $8.5 \pm 0.8$ & $5.5 \pm 0.7 * *$ \\
\hline Free $\mathrm{NAD}^{+} / \mathrm{NADH}_{\text {mitochondrial }}$ & $34 \pm 2$ & $17 \pm 3 * *$ \\
\hline Free $\mathrm{NAD}^{+} / \mathrm{NADH}_{\text {cytosolic }}$ & $466 \pm 56$ & $308 \pm 22 *$ \\
\hline \multicolumn{3}{|l|}{ Mouse } \\
\hline Pyruvate & $1.91 \pm 0.097$ & $1.72 \pm 0.152 *$ \\
\hline Lactate & $46 \pm 3$ & $47 \pm 3$ \\
\hline Glutamate & $12 \pm 1$ & $14 \pm 1$ \\
\hline$\alpha$-Ketoglutarate & $0.948 \pm 0.059$ & $1.09 \pm 0.09$ \\
\hline Ammonia & $6.7 \pm 0.3$ & $5.7 \pm 0.14 * *$ \\
\hline Free $\mathrm{NAD}^{+} / \mathrm{NADH}_{\text {mitochondrial }}$ & $14 \pm 2$ & $12 \pm 1$ \\
\hline Free $\mathrm{NAD}^{+} / \mathrm{NADH}_{\text {cytosolic }}$ & $378 \pm 21$ & $327 \pm 23$ \\
\hline
\end{tabular}

Valules are means \pm SEM, $n=8-10$

${ }^{*} p<0.05,{ }^{* *} p<0.01$ for difference from controls

in the pathogenesis of diabetic complications including diabetic retinopathy [1]. Like increased AR activity, it has been implicated in increased vascular permeability, leucostasis, accelerated retinal vascular cell apoptosis, formation of acellular capillaries and VEGF overexpression, as well as basement membrane thickening $[7,9,10,18,34$, 35]. Antioxidant treatment prevented or alleviated leucocyte adhesion to endothelial cells [7], VEGF overexpression $[9,36]$, increased vascular permeability [36], retinal cell apoptosis [18], basement membrane thickening [35] and formation of acellular capillaries $[10,18]$ in the retina of diabetic rats. In our study, mice with short-term STZ diabetes did not have evidence of enhanced retinal lipid peroxidation. Normal lipid peroxidation product concentration was probably maintained due to diabetes-associated upregulation of the key antioxidative defence enzymes, i.e. SOD, GSHPx, GSSGRed and GSHTrans. Evidently, mouse retina successfully builds an antioxidant defence under conditions of high glucose-induced free radical generation, whereas rat retina fails. Considering that SOD activity is 21 -fold higher in murine than in rat retina (the difference at least doubles under diabetic conditions), whereas other antioxidative enzyme activities are 3- to 10fold lower, SOD, i.e. the 'first line' of antioxidative defence against the primary free radical, superoxide, is likely to play a key role in counteracting retinal oxidative stress. Interestingly (and in contrast with findings in rats), catalase activity was reduced in the retina of diabetic mice. However, the decrease in catalase activity is comparable with the upregulation of GSHPx, another
$\mathrm{H}_{2} \mathrm{O}_{2}$-neutralising enzyme. The findings of normal MDA plus 4-HA concentrations as well as the absence of PARP activation (see below) suggest efficient $\mathrm{H}_{2} \mathrm{O}_{2}$ neutralisation by the retina of STZ-diabetic mice with a 6-week duration of diabetes.

Growing evidence indicates that oxidative stress contributes to mitogen-activated protein kinase and nuclear factor- $\mathrm{kB}$ activation, impaired calcium signalling, inflammation, and other events recently implicated in diabetic complications and, in particular, diabetic retinopathy [37-40]. One of the most important effectors of free radical and oxidant-induced DNA single-strand breakage is activation of the nuclear enzyme, PARP [41]. Evidence for an important role of PARP activation in diabetic retinopathy is emerging $[11,21,42]$. In our study, diabetic rats, but not mice, displayed increased poly(ADPribose) immunoreactivities in the retinal ganglion cell layer and inner neuronal layer. However, the number of poly(ADP-ribose)-positive nuclei was small and, correspondingly, an increase in poly(ADP-ribosyl)ated protein expression in western blot analysis was not statistically significant. No trend towards accumulation of poly(ADPribosyl)ated proteins was identified in diabetic mice. Note that recent reports suggest the presence of clearly manifest retinal PARP activation in both rats and mice with longer duration of diabetes $[11,27]$.

The role of $\mathrm{NAD}^{+} / \mathrm{NADH}$ redox imbalances in diabetic retinopathy has not been adequately elucidated, although some studies $[15,43]$ suggest that those play an important role in at least some diabetes-induced retinal changes, i.e. increase in vascular permeability. We have previously reported that decrease in free $\mathrm{NAD}^{+} / \mathrm{NADH}$ ratios is preventable by an AR inhibitor treatment [16], which counteracts diabetes-associated depletion of oxidised metabolites (pyruvate, $\alpha$-ketoglutarate) of free mitochondrial and cytosolic NAD-couples. In the present study, diabetes-associated free mitochondrial and cytosolic $\mathrm{NAD}^{+} / \mathrm{NADH}$ redox changes were clearly manifest in diabetic rats, but not in diabetic mice. The latter is consistent with modest sorbitol pathway activation, and the absence of other metabolic changes in the STZ-mouse model.

In conclusion, short-term STZ-diabetic rats have clearly manifest retinal sorbitol pathway hyperactivity, oxidative stress, PARP activation and $\mathrm{NAD}^{+} / \mathrm{NADH}$ redox imbalances, and therefore represent a good model for studying the role of these factors in neuroretinal apoptosis and glial changes associated with diabetes. In contrast, mice with a similar duration of STZ diabetes display a modest accumulation of sorbitol pathway intermediates, together with the absence of retinal oxidative stress, PARP activation or $\mathrm{NAD}^{+} / \mathrm{NADH}$ redox imbalances. This should be taken into account when 
selecting animal models for mechanistic studies of early retinal pathology associated with diabetes.

Acknowledgements This study was supported by the grants from the Juvenile Diabetes Research Foundation Center for the Study of Complications of Diabetes Grant 4-200-421 (I. G. Obrosova, A. K. Kumagai, M. J. Stevens) and the American Diabetes Association (I. G. Obrosova). The immunohistochemistry work was supported by the Intramural Research Program of the NIAAA/NIH (P. Pacher).

Duality of interest One of the authors (C. Szabo) was an employee of Inotek Pharmaceuticals. There was no duality of interest, as none of the studies involved Inotek products.

\section{References}

1. Frank RN (2004) Diabetic retinopathy. N Engl J Med 350: $48-58$

2. Frank RN, Amin R, Kennedy A, Hohman TC (1997) An aldose reductase inhibitor and aminoguanidine prevent vascular endothelial growth factor expression in rats with long-term galactosemia. Arch Ophthalmol 115:1036-1047

3. Kato N, Yashima S, Suzuki T, Nakayama Y, Jomori T (2003) Long-term treatment with fidarestat suppresses the development of diabetic retinopathy in STZ-induced diabetic rats. J Diabetes Complications 17:374-379

4. Dagher Z, Park YS, Asnaghi V, Hoehn T, Gerhardinger C, Lorenzi M (2004) Studies of rat and human retinas predict a role for the polyol pathway in human diabetic retinopathy. Diabetes 53:2404 2411

5. Kern TS, Tang J, Mizutani M et al (2000) Response of capillary cell death to aminoguanidine predicts the development of retinopathy: comparison of diabetes and galactosemia. Invest Ophthalmol Vis Sci 41:3972-3978

6. Ellis EA, Guberski DL, Hutson B, Grant MB (2002) Time course of NADH oxidase, inducible nitric oxide synthase and peroxynitrite in diabetic retinopathy in the BBZ/WOR rat. Nitric Oxide 6:295-304

7. Abiko T, Abiko A, Clermont AC et al (2003) Characterization of retinal leukostasis and hemodynamics in insulin resistance and diabetes: role of oxidants and protein kinase-C activation. Diabetes 52:829-837

8. Aiello LP, Bursell SE, Clermont A et al (1997) Vascular endothelial growth factor-induced retinal permeability is mediated by protein kinase $\mathrm{C}$ in vivo and suppressed by an orally effective beta-isoform-selective inhibitor. Diabetes 46:1473-1480

9. Obrosova IG, Minchenko AG, Marinescu V et al (2001) Antioxidants attenuate early up regulation of retinal vascular endothelial growth factor in streptozotocin-diabetic rats. Diabetologia 44:11021110

10. Kowluru RA, Tang J, Kern TS (2001) Abnormalities of retinal metabolism in diabetes and experimental galactosemia. VII. Effect of long-term administration of antioxidants on the development of retinopathy. Diabetes 50:1938-1942

11. Zheng L, Szabo C, Kern TS (2004) Poly(ADP-ribose) polymerase is involved in the development of diabetic retinopathy via regulation of nuclear factor-kappaB. Diabetes 53:2960-2967

12. Kador PF, Takahashi Y, Wyman M, Ferris F 3rd (1995) Diabeteslike proliferative retinal changes in galactose-fed dogs. Arch Ophthalmol 113:352-354
13. Neuenschwander H, Takahashi Y, Kador PF (1997) Dosedependent reduction of retinal vessel changes associated with diabetic retinopathy in galactose-fed dogs by the aldose reductase inhibitor M79175. J Ocular Pharmacol Ther 13:517-528

14. Obrosova IG, Minchenko AG, Vasupuram R et al (2003) Aldose reductase inhibitor fidarestat prevents retinal oxidative stress and vascular endothelial growth factor overexpression in streptozotocin-diabetic rats. Diabetes 52:864-871

15. Tilton RG, Chang K, Nyengaard JR, Van den Enden M, Ido Y, Williamson JR (1995) Inhibition of sorbitol dehydrogenase. Effects on vascular and neural dysfunction in streptozocininduced diabetic rats. Diabetes 44:234-242

16. Obrosova IG, Stevens MJ, Lang HJ (2001) Diabetes-induced changes in retinal NAD-redox status: pharmacological modulation and implications for pathogenesis of diabetic retinopathy. Pharmacology 62:172-180

17. Obrosova IG, Fathallah L, Greene DA (2000) Early changes in lipid peroxidation and antioxidative defense in diabetic rat retina: effect of DL-alpha-lipoic acid. Eur J Pharmacol 398:139-146

18. Kowluru RA, Odenbach S (2004) Effect of long-term administration of alpha-lipoic acid on retinal capillary cell death and the development of retinopathy in diabetic rats. Diabetes 53:32333238

19. Obrosova IG, Pacher P, Szabo C et al (2005) Aldose reductase inhibition counteracts oxidative-nitrosative stress and poly(ADPribose) polymerase activation in tissue sites for diabetes complications. Diabetes 54:234-242

20. Rota R, Chiavaroli C, Garay RP, Hannaert P (2004) Reduction of retinal albumin leakage by the antioxidant calcium dobesilate in streptozotocin-diabetic rats. Eur J Pharmacol 495:217-224

21. Obrosova IG, Minchenko AG, Frank RN et al (2004) Poly(ADPribose) polymerase inhibitors counteract diabetes- and hypoxiainduced retinal vascular endothelial growth factor overexpression. Int J Mol Med 14:55-64

22. Kowluru RA (2002) Retinal metabolic abnormalities in diabetic mouse: comparison with diabetic rat. Curr Eye Res 24:123-128

23. Obrosova IG, Fathallah L, Lang HJ, Greene DA (1999) Evaluation of a sorbitol dehydrogenase inhibitor on diabetic peripheral nerve metabolism: a prevention study. Diabetologia 42:1187-1194

24. Obrosova IG, Stevens MJ (1999) Effect of dietary taurine supplementation on GSH and NAD(P)-redox status, lipid peroxidation, and energy metabolism in diabetic precataractous lens. Invest Ophthalmol Vis Sci 40:680-688

25. Towbin H, Staehelin T, Gordon J (1992) Electrophoretic transfer of proteins from polyacrylamide gels to nitrocellulose sheets: procedure and some applications. 1979. Biotechnology 24:145149

26. Amano S, Yamagishi S, Kato N et al (2002) Sorbitol dehydrogenase overexpression potentiates glucose toxicity to cultured retinal pericytes. Biochem Biophys Res Commun 299:183-188

27. Cheung AK, Fung MK, Lo AC et al (2005) Aldose reductase deficiency prevents diabetes-induced blood-retinal barrier breakdown, apoptosis, and glial reactivation in the retina of $\mathrm{db} / \mathrm{db}$ mice. Diabetes 54:3119-3125

28. Cruz JW, Oliveira MA, Hohman TC, Fortes ZB (2000) Influence of tolrestat on the defective leukocyte-endothelial interaction in experimental diabetes. Eur J Pharmacol 391:163-174

29. Okayama N, Omi H, Okouchi M et al (2002) Mechanisms of inhibitory activity of the aldose reductase inhibitor, epalrestat, on high glucose-mediated endothelial injury: neutrophil-endothelial cell adhesion and surface expression of endothelial adhesion molecules. J Diabetes Complications 16:321-326

30. Miwa K, Nakamura J, Hamada Y et al (2003) The role of polyol pathway in glucose-induced apoptosis of cultured retinal pericytes. Diabetes Res Clin Pract 60:1-9 
31. Aukunuru JV, Sunkara G, Ayalasomayajula SP, DeRuiter J, Clark RC, Kompella UB (2002) A biodegradable injectable implant sustains systemic and ocular delivery of an aldose reductase inhibitor and ameliorates biochemical changes in a galactose-fed rat model for diabetic complications. Pharm Res 19:278-285

32. Asnaghi V, Gerhardinger C, Hoehn T, Adeboje A, Lorenzi M (2003) A role for the polyol pathway in the early neuroretinal apoptosis and glial changes induced by diabetes in the rat. Diabetes 52:506-511

33. Feit-Leichman RA, Kinouchi R, Takeda M et al (2005) Vascular damage in a mouse model of diabetic retinopathy: relation to neuronal and glial changes. Invest Ophthalmol Vis Sci 46:42814287

34. Ellis EA, Grant MB, Murray FT et al (1998) Increased NADH oxidase activity in the retina of the BBZ/Wor diabetic rat. Free Radic Biol Med 24:111-120

35. Robison WG Jr, Jacot JL, Katz ML, Glover JP (2000) Retinal vascular changes induced by the oxidative stress of alphatocopherol deficiency contrasted with diabetic microangiopathy. J Ocul Pharmacol Ther 16:109-120

36. Rota R, Chiavaroli C, Garay RP, Hannaert P (2004) Reduction of retinal albumin leakage by the antioxidant calcium dobesilate in streptozotocin-diabetic rats. Eur J Pharmacol 495:217-224
37. Purves T, Middlemas A, Agthong S et al (2001) A role for mitogen-activated protein kinases in the etiology of diabetic neuropathy. FASEB J 15:2508-2514

38. Romeo G, Liu WH, Asnaghi V, Kern TS, Lorenzi M (2002) Activation of nuclear factor-kappaB induced by diabetes and high glucose regulates a proapoptotic program in retinal pericytes. Diabetes 51:2241-2248

39. Li F, Obrosova IG, Abatan O et al (2005) Taurine replacement attenuates hyperalgesia and abnormal calcium signaling in sensory neurons of STZ-D rats. Am J Physiol Endocrinol Metab 288:E29E36

40. Joussen AM, Poulaki V, Le ML et al (2004) A central role for inflammation in the pathogenesis of diabetic retinopathy. FASEB J $18: 1450-1452$

41. Jagtap P, Szabo C (2005) Poly(ADP-ribose) polymerase and the therapeutic effects of its inhibitors. Nat Rev Drug Discov 4:421440

42. Sugawara R, Hikichi T, Kitaya N et al (2004) Peroxynitrite decomposition catalyst, FP15, and poly(ADP-ribose) polymerase inhibitor, PJ34, inhibit leukocyte entrapment in the retinal microcirculation of diabetic rats. Curr Eye Res 29:11-16

43. Williamson JR, Chang K, Frangos M et al (1993) Hyperglycemic pseudohypoxia and diabetic complications. Diabetes 42:801-813 